\title{
Genetically Modified Baker's Yeast Saccharomyces cerevisiae in Chemical Synthesis and Biotransformations
}

\author{
Ewa Białecka-Florjańczyk and Agata Urszula Kapturowska \\ Warsaw University of Life Sciences, Faculty of Food Sciences, Department of Chemistry \\ Poland
}

\section{Introduction}

Yeast Saccharomyces cerevisiae has been associated with human beings for more than 6000 years due to its use in food production, baking, wine and beer making. Potable and industrial ethanol production constitutes the majority of use of $S$. cerevisiae in biotechnological applications. However, baker's yeast also plays an important role as a model organism in the field of biochemistry, genetics and molecular biology. S. cerevisiae was the first eukaryotic organism to be sequenced in 1996 [Goffeau et al., 1996], and is clearly the most ideal eukaryotic microorganism for biological studies. Furthermore, the ease of genetic manipulation of yeast allows it to be used for analyzing and functionally dissecting gene products from other eukaryotes. The field of metabolic engineering, which utilizes genetic tools to manipulate microbial metabolism to enhance the production of compounds of interest has a particularly strong impact by providing new platforms for chemical production and facilitating the expansion of industrial (white) biotechnology [Nevoigt, 2008]. Baker's yeast can also be used as host organism for novel production of some industrially relevant chemicals. Our review focuses on the progress that has been achieved in the production of fine chemicals, bulk chemicals and fuels by genetic manipulation of the enzymatic activity of yeast, the combining of enzyme pathways from different microorganisms into S. cerevisiae and expressing genes from S. cerevisiae in other hosts. Attention to biotransformations catalyzed by genetically modified yeast will also be considered.

\section{Bioethanol production}

Bioethanol is usually obtained from the conversion of carbon based renewable feedstock and can be used as a fuel for vehicles in its pure form or as a gasoline additive to increase octane rating and improve vehicle emissions. Bioethanol is primarily produced by fermentation of sugar or the sugar components of starch. However, there has been constant research on its production from fibrous substances such as cellulose and hemicelluloses, which make up the bulk of most plant matter. Two chemical reactions take place during biomass conversion to ethanol: the hydrolysis of complex polysaccharides in the raw feedstock to simple sugars followed by their subsequent fermentation to ethanol. The second step of bioethanol production is caused by yeast or bacteria which feed upon the sugars. Therefore high ethanol 
yields from lignocellulosic biomass from agricultural and agro-industrial residues are dependent upon efficient hydrolysis of sugar polymers and utilization of all the available sugars including D-glucose, D-xylose, L-arabinose and other fermentable compounds.

S. cerevisiae, which plays a traditional and major role in industrial bioethanol production, has several advantages due to its high ethanol productivity as well as its high ethanol tolerance. However, baker's yeast cannot hydrolyze cellulose and is not able to use pentoses, which constitute up to $20 \%$ of lignocellulosic biomass. Many studies regarding the use of $S$. cerevisiae in metabolic engineering for xylose utilization have been reported and several reviews have been published [Chu \& Lee, 2007; Hahn-Hägerdal et al., 2007; Matsushika et al., 2009]. The first step of D-xylose metabolism is its direct isomerization to D-xylulose catalyzed by bacterial xylose isomerase XR (EC 5.3.1.5) or stepwise transformation in yeast cells, firstly to xylitol (xylose reductase XR EC 1.1.1.21) and then to D-xylulose (xylitol dehydrogenase XDH EC 1.1.1.19). After phosphorylation of D-xylulose to D-xylulose-5phosphate (xylulokinase XK EC 2.7.1.17) further metabolizm proceeds via a pentose phosphate pathway. Different strategies have been applied to engineering yeast including the introduction of initial xylose metabolism and xylose transport. However, these change the intracellular redox balance and result in over-expression of xylulokinase and further metabolism via a pentose phosphate pathway. Nevertheless they are insufficient for industrial bioprocesses mainly due to a low rate of reaction as compared with glucose fermentation [Kondo et al. 2010; Young et al., 2010].

\section{Yeast cells as microbial chemical factories}

Many plant secondary metabolites (i.e. small molecules, with complicated structures which are not involved in basic metabolic pathways and are not directly essential for photosynthetic or respiratory processes) have been identified as having beneficial effects on human health or nutrition, but their chemical synthesis is generally laborious and their isolation from natural sources is a difficult process with low yields. Furthermore, there is a wide range of chemicals essential in many industries as substrates in production processes or compounds necessary for appropriate process progress, that are produced by many microorganisms with low efficiency or during chemical synthesis, which is nowadays considered as non-ecological.

Baker's yeast can produce a diverse array of secondary metabolites [Pscheidt \& Glieder, 2008], therefore the metabolic engineering of microorganisms is a new area of effective biosynthesis of these compounds and yeast is an important and attractive host for the heterologous and function expression of foreign genes encoding many important secondary metabolites of plants. Moreover baker's yeast possesses GRAS status, which is an advantage in the production of compounds that are intended for human consumption (e.g. the formation of antioxidants and aroma compounds during wine fermentation). A few examples in which modified S. cerevisiae were used as a whole-cell factories in production of chosen chemical compounds are presented in this chapter.

\subsection{Alcohols (other than ethanol)}

\subsubsection{Butan-1-ol}

Butan-1-ol can be regarded as superior biofuel to ethanol because of its greater hydrophobicity, higher energy density and the possibility of mixing with gasoline and 
transporting through existing pipeline infrastructure. Microbial butanol production is performed by members of the genus Clostridium [Inui et al. 2008]. The butanol pathway is expressed in S. cerevisiae from a range of organisms (Escherichia coli, Clostridium beijerinckii and Ralstonia eutropha) and owing to the tolerance of baker's yeast to alcohols, the production of butanol is raised ten-fold to $2.5 \mathrm{mg} \mathrm{dm}^{-3}$. The most productive strains harbour the $C$. beijerinckii 3-hydroxybutyryl-CoA dehydrogenase, which uses NADH as a co-factor, and the acetoacetyl-CoA transferase from S. cerevisiae or E. coli [Steen et al., 2008].

\subsubsection{Glycerol}

Glycerol is considered to have a positive effect on the sensory properties of wine. Its concentration in wine varies between $1-15 \mathrm{~g} / \mathrm{dm}^{3}$. Many growth and environmental factors have been reported to influence the amount of glycerol produced by yeast in wine. In $S$. cerevisiae metabolism glycerol is a byproduct of the fermentation of sugar to ethanol. It is synthesized in the cytosol from dihydroxyacetone phosphate in two steps that are catalyzed by glycerol-3-phosphate dehydrogenase (GPDH) and glycerol-3-phosphatase (GPP) respectively. The former is the key enzyme in glycerol production [Wang et al., 2001]. More recently, genetic engineering approaches have been successful in redirecting the carbon flux towards glycerol. GPDH, a limiting enzyme for glycerol formation, is encoded by GPD1 and GPD2 genes. Overexpression of GPD1 in a laboratory strain of baker's yeast and in a haploid strain V5 resulted in a marked increase in glycerol production at the expense of ethanol. Up to $28 \mathrm{~g}$ of glycerol per liter was formed by an engineered S. cerevisiae strain under conditions simulating wine fermentation [Remize et al., 1999].

Nowadays, the demand for glycerol is restricted due to the large quantity of glycerol generated during biodiesel production, so this direction of study is impractical.

\subsubsection{Propane-1,3-diol}

Propane-1,3-diol (1,3-PD) has numerous applications in production of polymers for cosmetics, foods, lubricants and medicines. Recently, there has been a strong industrial interests in a new kind of polyester, poly(trimethylene terephtalate), with 1,3-PD as a monomer. Nevertheless, its availability is restricted owing to its expensive chemical synthesis.

Non-modified S. cerevisiae can produce glycerol from D-glucose but cannot synthesize 1,3propanediol. By taking advantage of genetically engineered $S$. cerevisiae 1,3-PD production is possible in two ways [Celińska, 2010]. One is to clone the yqhD gene from E. coli and dhaB gene from K. pneumonia required for the production of propane-1,3-diol from glycerol, and to integrate them into the chromosome W303-1A of S. cerevisiae by the Agrobacterium tumefaciens genetic transfer system. Both the $\mathrm{yqhD}$ and $\mathrm{dhaB}$ genes function in the engineered S. cerevisiae and lead to the production of 1,3-propanediol from D-glucose, but the amount of 1,3-PD is relatively small, due to low availability of glycerol in the reaction medium [Rao et al., 2008]. An alternative method of microbial 1,3-PD synthesis is described by Mendes et. al. using two recombinant microorganisms. The first step of the process is the conversion of sugar into glycerol by the metabolic engineered Saccharomyces cerevisiae strain HC42 adapted to high glucose concentrations (> $\left.200 \mathrm{~g} \mathrm{dm}^{-3}\right)$. The second step, carried out in the same bioreactor, is performed by the engineered strain Clostridium acetobutylicum DG1 (pSPD5) which converts glycerol to propane-1,3-diol [Mendes et al., 2011]. 


\subsection{Organic acids - Pyruvic, lactic and malic}

Saccharomyces cerevisiae does not naturally produce organic acids in large amounts, but its robustness and $\mathrm{pH}$ tolerance make it an excellent microorganism for researches in this field [Abbott et al., 2009]. The first attempts involved blocking the ethanol formation via deletion of four structural genes for alcohol dehydrogenase. Better results were obtained by eliminating the pyruvate decarboxylase (PDC) activity. Deletion of all three PDC genes completely eliminated alcoholic fermentation. Aerobic fermentation at $\mathrm{pH} 5$ yielded pyruvic acid (fig. 1) at a concentration of aproximately $135 \mathrm{~g} \mathrm{dm}^{-3}$ [Ischida et al., 2006]. The strategy for lactic acid (fig. 1) production consisted of two steps - deletion of one or more of three functional genes encoding pyruvate decarboxylase and the introduction of the bovine lactate dehydrogenase (L-LDH) in the genome under the control of PDC1 promoter.

Two enzymes, pyruvate carboxylase and malate dehydrogenase, produced by S. cerevisiae are involved in L-malic acid accumulation (Fig. 1). Overexpression of cytosolic malate dehydrogenase (MDH2) caused up to a 3.7 fold increase in L-malic acid production and an elevated accumulation of fumaric and citric acids [Pines et al., 1997]. Alternative way of Lmalic production, including biotransformations, will be described in the chapter 4.4.<smiles>CC(=O)C(=O)O</smiles>

pyruvic acid<smiles>CC(O)C(=O)O</smiles>

lactic acid<smiles>O=C(O)CC(O)C(=O)O</smiles>

malic acid

Fig. 1. Organic acids produced by genetically modified S. cerevisiae

\subsubsection{Sugar alcohols}

Sugar alcohols (polyols, Fig. 2) can be synthesized from carbohydrates as a result of carbonyl group reduction to a hydroxyl one and can be used as a sweetners. Xylitol is the most popular one, due to its lower energy value than sucrose and the comparable sweetening power.<smiles>OC[C@H](O)[C@H](O)[C@H](O)CO</smiles><smiles>OC[C@H](O)[C@H](O)[C@H](O)CO</smiles>

xylitol

ribitol

Fig. 2. Sugar alcohols

Toivari et al described recombinant Saccharomyces cerevisiae strains that produce xylitol and ribitol from D-glucose in a single fermentation step. 8.5-fold enhancement of the total amount of the excreted sugar alcohols was achieved via expression of the xylitol dehydrogenase-encoding gene XYL2 of Pichia stipitis in the transketolase-deficient strain of S. cerevisiae. The additional introduction of the 2-deoxy-glucose 6-phosphate phosphataseencoding gene DOG1 into the transketolase-deficient strain expressing the XYL2 gene induced further 1.6-fold increase in ribitol production [Toivari et al., 2007] 


\subsection{Lipid compounds}

\subsubsection{Fatty acids}

Fatty acids are of considerable interest due to their pharmaceutical and nutritional values. These compounds are also necessary for cellular functions such as regulation of membrane fluidity. Saccharomyces cerevisiae are able to synthesize de novo only some saturated and monounsaturated fatty acids, mainly the C-16 and C-18 acids [Daum et al., 1998]. To reconstitute other long-chain and polyunsaturated fatty acids it is necessary to introduce genes of suitable enzymes such as desaturases and elongases eg. A. thaliana oleate desaturase gene (FAD2) or fatty acid desaturase from the fungus $M$. alpina. The simultaneous expression of $\Delta^{12}$-desaturase and $\Delta^{6}$-desaturase from $M$. alpina resulted in an increase in the content of $\gamma$-linolenic acid (18:3) to $8 \%$ of total fatty acids in yeast cells [Veen \& Lang, 2004].

Due to the important roles of polyunsaturated fatty acids (PUFAs) in human health and nutrition the effect of overexpression of cytochrome b5 genes on fatty acid desaturation has been explored. The modification does not affect the fatty acid synthesis very much, but significantly enhances the synthesis of PUFA at $30^{\circ} \mathrm{C}$ [Yazawa et al., 2010]. A number of desaturases from different sources (e.g. Mucor rouxii, M. alpine) have been functionally expressed in S. cerevisiae with a view to attain PUFAs formation [Chemler et al., 2006].

\subsubsection{Isoprenoids}

Isoprenoids (terpenoids) are ubiquitous in nature. They are a structurally diverse group of compounds and range from essential cell components to unique secondary metabolites. Terpenoids are based on combinations of isoprene units $\left(\mathrm{C}_{5} \mathrm{H}_{8}\right)$, and their carbon skeleton is multiples of five carbon atoms e.g. monoterpenoids (10-carbon), sesquiterpenoids (15carbon), diterpenoids (20-carbon) and carotenoids (40-carbon). Biosynthesis of these compounds proceeds via formation of isopentenyl pyrophosphate (IPP), dimethylallyl pyrophosphate (DMAPP), geranyl pyrophosphate (GPP), farnesyl pyrophosphate (FPP), and geranylgeranyl pyrophosphate (GGPP) (Fig. 3).
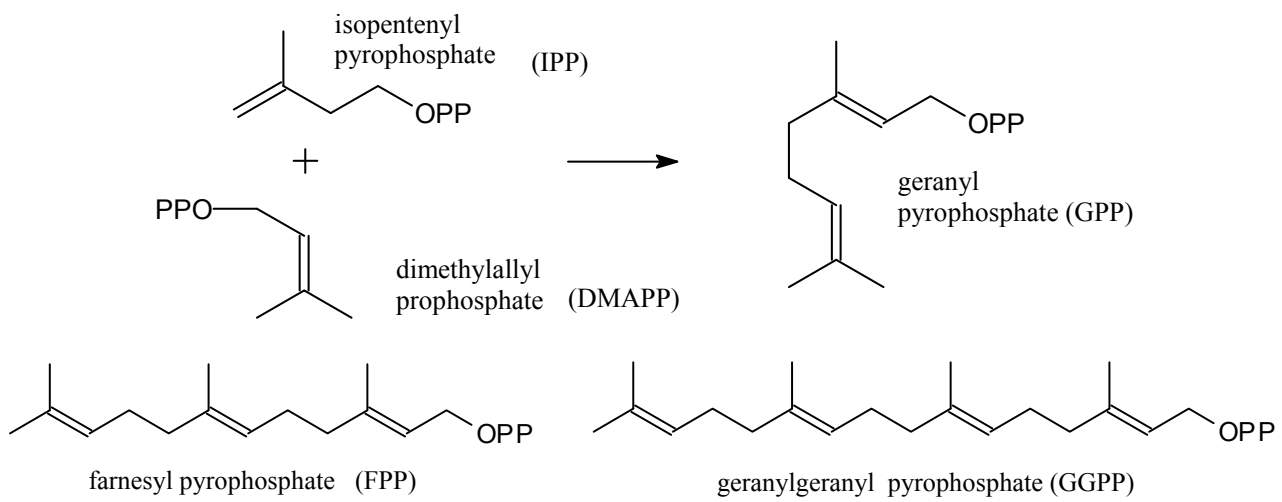

Fig. 3. Some terpene alcohols pyrophosphates - precursors of other terpenoids (OPPpyrophosphate group) 
Isoprenoids exist in low concentrations in their host organisms. They are complex molecules with a specified stereochemical structure, which makes them difficult to synthesize by chemical methods. Therefore, these compounds are of particular interest for microbial production. E. coli, A. thaliana and S. cerevisiae are the organisms with the most advanced genetic tools and are applied as heterologous hosts for terpenoids production, but they usually have very limited isoprenoid secondary metabolism minimizing competing metabolic fluxes.

Phosphorylated derivatives of geraniol (monoterpene) and geranylgeraniol (diterpene) are important molecules in the synthesis of various isoprenoids. $(E, E, E)$-geranylgeranyl pyrophosphate (GGPP) is an intermediate in carotenoids and ubiquinone biosynthesis [Tokuhiro et al., 2009] and was synthesized in engineered S. cerevisiae as a result of enhancement of the mevalonate pathway and redirection of carbon flux through overexpression of several key enzymes. The production achieved was $70.9 \mathrm{mg} \mathrm{g}^{-1}$ of dry cell weight (3.31 $\left.\mathrm{g} \mathrm{dm}^{-3}\right)$, which is very high in comparison to the production of other isoprenoids reported in the literature (e.g. $5.9 \mathrm{mg} \mathrm{g}^{-1}$ for carotene) [Verwaal et al., 2007].

Commercially important terpenoids are artemisinin and paclitaxel, so much work has focused on the introduction of exogenic metabolism in yeast to synthesize the precursors of these compounds [Chang \& Keasling, 2006; Huang et al., 2008].

Artemisinin, an endoperoxide sesquiterpene lactone (Fig 4), was originally isolated from the chinese plant Artemisia annua. Its derivatives are now a group of drugs used worldwide for the treatment of malaria by means of artemisinin-combination therapies (ACTs). Engineered yeast systems are able to produce artemisinin or its precursor (artemisinic acid), which can be converted to artemisinin via chemical reactions (Fig. 4) [Shiba et al., 2007; Arsenault et al., 2008].

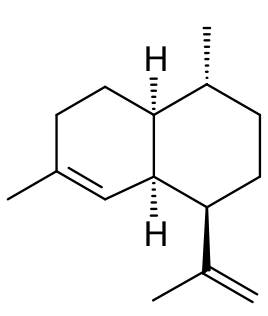

Amorpha-4,11-diene

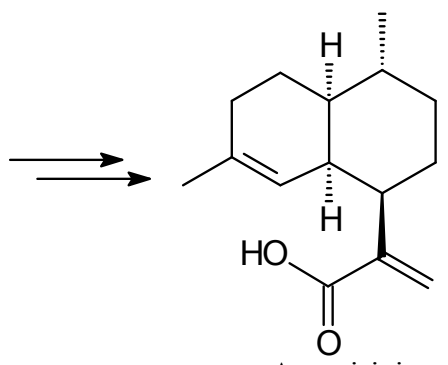

Artemisinic acid

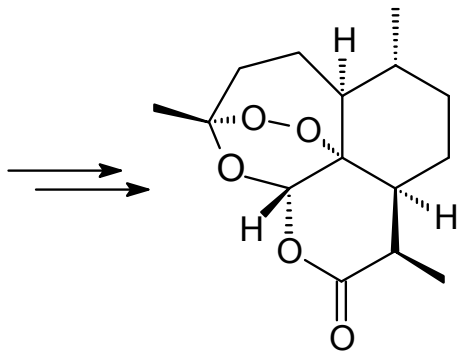

Artemisinin

Fig. 4. Synthesis of artemisinin [Ro et al., 2006]

Ro et al. cloned a gene from A. annua, which codes a cytochrome $\mathrm{P} 450$, enabling the transformation of amorpha-4,11-diene to artemisinic acid, which in turn was converted to artemisinin by chemical synthesis [Ro et al., 2006]. In order to achieve a higher yield of amorpha-4,11-diene (Fig. 4), which is synthesized by cyclization of farnesyl pyrophosphate Shiba et al. engineered the pyruvate dehydrogenase bypass in S. cerevisiae [Shiba et al., 2007].

A partial biosynthesis of paclitaxel (trade name taxol, Fig. 5) - terpenoid, which is widely used in cancer therapy and produced as a secondary metabolite of yew trees (Taxus sp.), was 
constructed in S. cerevisiae. Dejong reported the functional expression of eight taxoid biosynthetic genes from Taxus brevifolia in yeast, elevating the accumulation of intermediate taxadiene [Dejong et al., 2006].

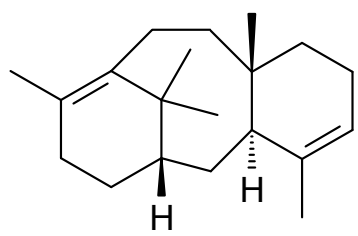

Taxadiene

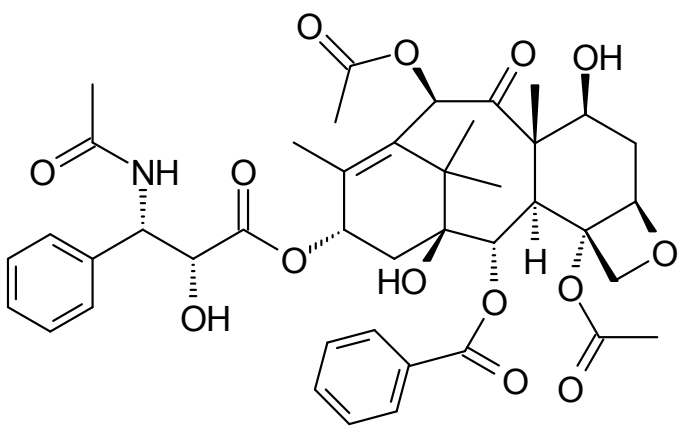

Paclitaxel

Fig. 5. Taxadiene and paclitaxel [Dejong et al., 2006]

Another way of synthesis of taxol building blocks is the biotransformation catalyzed by modified whole cell S. cerevisiae catalysts. This will be described in chapter 4.1.

\subsubsection{Steroids}

Steroids are the other group of compounds originating from the terpenoids precursors dimethylallyl pyrophosphate and isoprenylpyrophosphate (Fig. 3). One of them, hydrocortisone (Fig. 6), is an important starting material for synthesis of drugs with antiinflammatory effect.

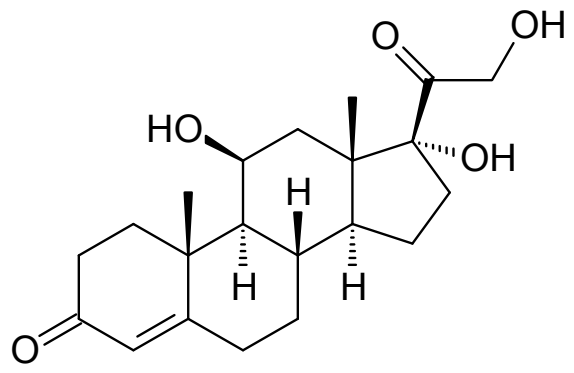

Fig. 6. Hydrocortisone

Hydrocortisone can be synthesized in Sacharomyces cerevisiae cells from simple carbon sources [Szczebara et al., 2003]. To optimize its yield the natural yeast pathway for sterols synthesis was rerouted after expressing genes from one plant enzyme and eight mammalian proteins including four of the P450 superfamily oxidases, three electron carriers and $3 \beta$-hydroxysterol oxidase/isomerase ( $3 \beta$-HSD). Under optimum conditions, a $70 \%$ yield of hydrocortisone was produced from the total steroid formation from glucose [Dumas et al., 2006]. 


\subsection{Flavonoids}

Flavonoids are a diverse class of plant secondary metabolites derived from the phenylpropanoid pathway. There has been increasing interest in flavonoids because many of them exhibit antioxidative activity due to free-radical scavenging. This is an attractive feature for drugs in coronary heart disease prevention and anticancer activity.<smiles>O=C1CC(c2ccc(O)cc2)Oc2cc(O)cc(O)c21</smiles>

Fig. 7. Naringenin - flavanone

The biosynthesis of flavanone naringenin (Fig. 7), the central precursor of many flavonoids, is accomplished by introducing the phenylpropanoid pathway into Saccharomyces cerevisiae strains. It is achieved with the genes for phenylalanine ammonia lyase (PAL) from Rhodosporidium toruloides, 4-coumarate:coenzyme A (CoA) ligase (4CL) from Arabidopsis thaliana and chalcone synthase (CHS) from Hypericum androsaemum [Jiang et al., 2005] or with plant genes from heterologous origin such as 4-coumarate:coenzyme A ligase 4CL from Petroselium crispum, chalcone synthetases CHS from Medicago sativa and Petunia x hybrida and chalcone reductase CHR and chalcone isomerase from $M$. sativa [Yan et al., 2005].

Another method to produce flavonoid or isoflavonoid compounds in engineered yeast is to clone five soybean (Glycine max) chalcone isomerases (CHIs), key enzymes in the phenylpropanoid pathway [Ralston et al., 2005].

\section{Biotransformations catalyzed by yeast cells}

Baker's yeast may be considered as a producer of wide range of chemical compounds, a kind of microbial cell factory. However, Saccharomyces cerevisiae is a commonly applied to whole-cell biocatalysis in biotransformation, reactions based on enzymatic transformations of chemical compounds. Biotransformations, known as a branch of "white" biotechnology, provide efficient procedures in organic synthesis owing to the high chemo- and stereoselectivity of enzymes and offer a viable alternatives to chemical methods. Today, biotransfomation is a commonly accepted method for generating optically pure substances and for developing efficient synthesis of target compounds. In general, biotransformations are performed by the hydrolases or oxidoreductases. The remaining classes (transferases, isomerases, liases and ligases) are of lower, but increasing utility [Faber 2004].

Biotransformations may be carried out using isolated enzymes or microorganisms cells producing enzymes (whole-cell biocatalysis). The application of isolated and purified enzymes is profitable since the formation of undesired byproducts is avoided, whereas in cellular biotransformation systems undesirable product formation is possible due to the presence of other enzymes or simultaneous catalysis of several reactions. However the whole-cell biocatalysis has two important advantages: it is particularly beneficial when 
the regeneration of the cofactor is necessary (e.g. in redox reactions) and is favorable due to the cost effectiveness.

Baker's yeast has a great potential as a catalysts in organic chemistry owing to ease of handling, broad substrate acceptability and production of enzymes belonging to different classes. S. cerevisiae may be used in dry and pressed form, as raw yeast or lyophilized biomass and is capable of catalyzing many reactions in water or in organic media. These features are very important for chemists, because chemical laboratories are not usually equipped with the microbiological apparatus required for yeast cultivation [Csuk \& Glanzer 1991; Servi, 1990; Białecka-Florjańczyk \& Majewska, 2006].

The full sequencing of the $S$. cerevisiae genome, accompanied with the achievements in genetic engineering, have allowed new strains of yeast to be designed with specific high conversion yields and reaction selectivity. There is a growing interest in application of modified yeast in biotransformation reactions. Modern directions to improve catalytic abilities of baker's yeast include the use of surface display technology for enzymes and optimization or increase in availability of cofactor (required for bio-reduction reactions) or gene knock-out, to eliminate the activity of enzymes with conflicting and unwanted stereoselectivities. As commonly used technique is overexpression of the desired protein or expression of heterologous enzymes in yeast cells.

\subsection{Reduction of carbonyl compounds}

Baker's yeast is considered to produce over 20 different reductases. At present most of the characterized carbonyl (and dicarbonyl)-reducing enzymes of S. cerevisiae are grouped into two distinct protein categories - the aldo-keto reductase (AKR) and the short-chain dehydrogenase/reductase (SDR) superfamilies. They have been shown to reduce a broad array of ketones and ketoesters with different enantioselectivity and to have overlapping activities [Katz et al., 2003]. Reductions catalyzed with baker's yeast require the presence of nicotinoamide cofactors (mostly NADPH) [Johanson et al., 2005], which can be regenerated during the growth of microorganisms.

Enantioselectivity (or diastereoselectivity) of carbonyl compounds reduction is connected with the formation of an asymmetric center in the product (alcohol) molecule (Fig. 8). According to Csuk et al. and Servi, reduction of aliphatic methyl ketones using baker's yeast leads to synthesis of secondary alcohols with the $(S)$ configuration [Csuk, Glanzer 1991; Servi, 1990].

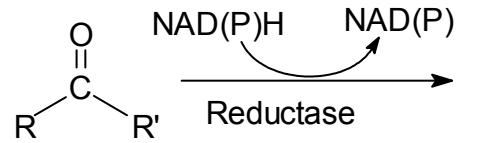<smiles>[R]C([R])([2H])O</smiles>
and/or<smiles>[R]C([R])([2H])O</smiles>

Fig. 8. Two enantiomeric alcohols formed during the reduction of carbonyl compound

Practical difficulties associated with the use of yeast as a chiral reducing agent arise from the presence of multiple enzymes overlapping substrate characteristics, but with differing enantio- and diastereoselectivities. Nakamura et al. isolated and characterized four oxidoreductases of raw baker's yeast in the reduction of 4-chloro-3-oxobutanoate [Nakamura et al., 1999]. The enantioselectivity of all of the enzymes examined was $>99 \%$, 
but two of them produced $(R)$ and the others $(S)$ isomers. Thus the different specificity of enzymes produced by $S$. cerevisiae is the reason for the low specificity of unmodified cells in this biotransformation. A recombinant Saccharomyces cerevisiae strain over-expressing the fatty acid synthase of $S$. cerevisiae (FAS) and the glucose dehydrogenase of Bacillus subtilis was applied by Engelking et al. for enantioselective reduction of ethyl 4-chloro-3oxobutanoate to ethyl (S)-4-chloro-3-hydroxybutanoate (Fig. 9) as well as the reduction of ethyl benzoylacetate to ethyl (S)-3-hydroxy-3-phenylpropanoate. The enantiomeric excess (ee) was $90 \%$ in the case of the former and $>97 \%$ in the case of the latter product [Engelking et al., 2006].<smiles>CCOC(=O)CC(=O)CC(O)CCl</smiles>

Fig. 9. Bioreduction of ethyl 4-chloroacetylacetate with S. cerevisiae yeast [Engelking et al., 2006]

A method performed by Rodriguez et al. involved modified baker's yeast for $\beta$-ketoesters reduction by using recombinant DNA techniques such as overexpression of carbonyl reductase with desirable stereoselectivities. Manipulating the levels of three proteins, fatty acid synthase, (Fasp); aldo-ketoreductase, (Ypr1p); a-acetoxy ketone reductase, (Gre2p) the stereoselectivity of $\beta$-ketoester reduction was improved and reached $>85 \%$ in all cases [Rodriguez et al., 2001]. Conversely, the strain lacking aldo-ketoreductase produced hydroxyester with reversed stereoselectivity from unmodified baker yeast [Rodriguez et al., 1999].

One example of efficient genetic modification concerns the asymmetric reduction of the bicyclic diketone (Fig. 10) bicyclo[2.2.2]octane-2,6-dione (1) to $(1 R, 4 S, 6 S)$-6-hydroxybicyclo[2.2.2] octane-2-one ((-)-2), which is used as an intermediate in the synthesis of transition metal based chiral chemical catalysts [Sarvary et al., 2001; Katz et al., 2002]. When carrying out the experiment with baker's yeast, ketoalcohol (-)-2 was obtained in $92-97 \%$ enantiomeric excess with $92 \%$ yield [Almqvist et al., 1993], but the diastereoselectivity of reduction of bicyclo[2.2.2] octane-2,6-dione catalyzed by whole cells of a modified strain of $S$. cerevisiae TMB4110 overexpressing the reductase gene YDR368w, was significantly improved. The product was achieved with $97 \%$ diastereomeric excess (de) and $>99$ enantiomeric excess (ee) [Johanson et al., 2008; Parachin et al., 2009].
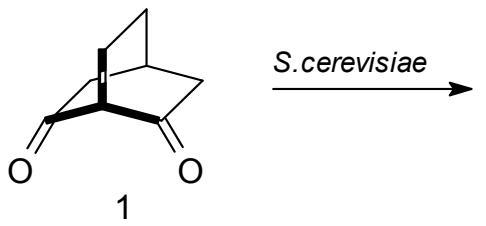

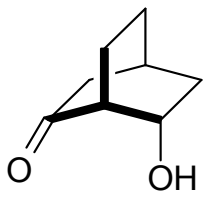

$(-)-2$

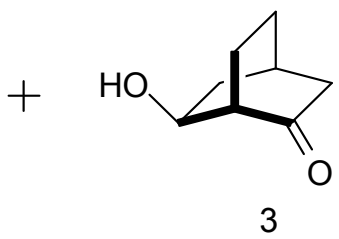

3

Fig. 10. Reduction of bicyclo[2.2.2]octane-2,6-dione (1) [Katz et al., 2003]

Another practical solution of this problem was uncovered by expression of appropriate endogenous enzymes in host cells, which do not produce these proteins. For example, expression of GCY1 and GRE3 genes from S. cerevisiae in E. coli cells achieved chiral $\beta$ - 
hydroxyesters with high optical purities with over $98 \%$ enantiomeric excess [Rodriguez et al., 2000].

Genetically modified cells of $S$. cerevisiae can catalyze biotransformation reaction, producing chiral building blocks important in the pharmaceutical industry (especially those obtained by reduction of $\alpha-$ and $\beta$-oxoesters or amides). Optically pure alcohols are important chiral blocks in the synthesis of valuable pharmaceuticals such as carnitine (required for the transport of fatty acids from the cytosol into the mitochondria during the breakdown of lipids) or paclitaxel [Stewart, 2000]. Using the structural analogy between substrate and molecules of $\beta$-oxothioesters participating in biosynthesis of fatty acids, the $S$. cerevisiae strain with punctual mutation in the FAS-2 gene (fatty acid synthase) catalyzed the stereoselective reduction of the ketone group in the $\beta$-lactam molecule (Fig. 11), eliminating trans-isomer [Kayser et al., 1999]. This reduction was applied in the synthesis of the paclitaxel (after coupling with readily available 10-deacetylbaccatin III) with a $\mathrm{C}_{13}$ side chain - $(2 R, 3 S)$-N-benzoyl-3-phenylisoserine.
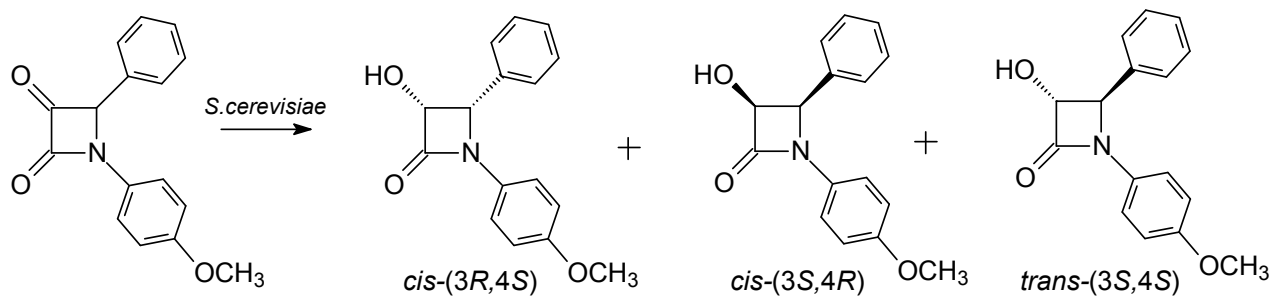

Fig. 11. Baker's yeast reduction of $\beta$-keto-a-lactam [Kayser et al., 1999]

Application of pure enzymatic preparations in organic chemistry generates a demand for coenzymes, which have to be added to the reaction medium. The use of baker's yeast in oxidoreductions is interesting, due to the ability of $S$. cerevisiae cells to synthesize not only the molecules of the specific enzymes, but also an essential coenzymes [Faber, 2004].

Although improvement of enantiomeric excess is critical for the product yield, regeneration of the co-factor is also important. This can be improved by genetic engineering. S. cerevisiae dicarbonyl reductases are NADPH-dependent and the reduced co-factor NADPH requires regeneration through the assimilation of a co-product, usually glucose, sucrose or ethanol. Glucose can be used as a co-substrate under both aerobic and anaerobic conditions. Unfortunately yeast generates large amounts of by-products from glucose, which may cause problems during downstream processing, with large amounts of glucose required to reduce small amounts of substrate. Ethanol is an interesting alternative to glucose as a co-substrate since it has a much lower utilisation rate and generate less $\mathrm{CO}_{2}$. However, ethanol is toxic to the cells at high concentrations and NADPH cannot be regenerated from ethanol under anaerobic conditions.

Strain engineering for the design of efficient biocatalysts using glucose as a co-substrate has two potential objectives, to redirect the carbon flow towards NADPH-regenerating pathways and to slow down the rate of co-substrate utilisation in order to balance the reduction rate. In the $S$. cerevisiae strain the activity of phosphoglucose isomerase (PGI) was decreased and the baker's yeast strain alcohol dehydrogenase activity was deleted. In both cases the glucose consumption was limited without lost of reductase activity [Johanson et 
al., 2005]. The yeast phosphoglucose isomerase activity was decreased, and the short-chain dehydrogenase/reductase encoded by YMR226c was overexpressed in the genetically engineered Saccharomyces cerevisiae strain TMB4100 (1\% PGI, YMR226c).

The whole cell biocatalyst was used for the kinetic resolution of racemic bicyclo[3.3.1]nonane-2,6-dione (rac-1, Fig. 12). This framework is a commonly occurring motif amongst natural products, displaying a wide scope of biological activities. Genetic modification reduced the demand for the glucose to regenerate NADPH, resulted in a greater reaction rate and produced higher selectivity towards the (+)-1 stereoisomer, reaching an enantiomeric excess of $100 \%$ after $75 \%$ conversion of the isomer (Fig.12) [Carlquist et al., 2008].

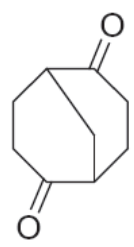

rac-1

\section{S.cerevisiae}

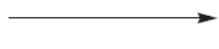

$(+)-1$

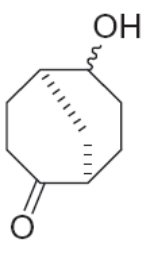

2

Fig. 12. Kinetic resolution of bicyclo[3.3.1]nonane-2,6-dione by genetically modified baker's yeast [Carlquist et al., 2008]

In addition (+)-5,6-epoxybicyclo[2.2.1]heptane-2-one, ((+)-1, Fig. 12), and endo-(-)-5,6epoxybicyclo [2.2.1] heptane-2-ol, endo-(-)-2, were obtained by asymmetric bioreduction catalyzed by the same $S$. cerevisiae yeast strain. Rac-1 was kinetically resolved to give (+)-1 with 95\% enantiomeric excess and endo-(-)-2 with 74\% enantiomeric excess (Fig. 13) [Carlquist et al., 2009].<smiles></smiles>

rac-1

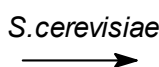

$\mathrm{O}$

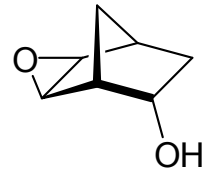

endo-(-)-2

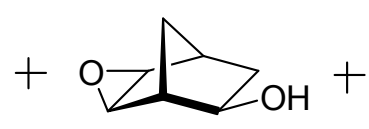

exo-2

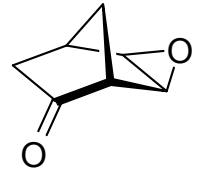

$(+)-1$

Fig. 13. Kinetic resolution of 5,6-epoxybicyclo[2.2.1] heptan-2-one [Carlquist et al., 2009]

\subsection{Baeyer-Villiger oxidation}

"Designer yeast" is a new catalyst for Baeyer-Villiger (BV) oxidation, an organic reaction in which a ketone is oxidized to an ester by treatment with peroxy acids (Fig. 14).<smiles>[R]OC([R])=O</smiles>

Fig. 14. Baeyer-Villiger reaction 
The enzymatic Baeyer-Villiger oxidation represents an efficient approach to the asymmetric synthesis of chiral lactones and can be performed by biocatalysis with flavoenzymes called Baeyer-Villiger monooxygenases (BVMOs). BVMOs catalyze nucleophilic oxidation of ketones as well as electrophilic oxidation of heteroatoms such as boron, sulfur, selenium, nitrogen or phosphorus in organic compounds. Depending on the type of cofactor necessary for running the reaction BVMOs are distinguished between FAD- and NADPH-dependent enzymes and FMN- and NADH-dependent enzymes. Baeyer-Villiger monooxygenases are produced by the bacteria Acinetobacter sp. and Pseudomonas sp. and fungi such as Aspergillus sp. [Alphand et al., 2003]. Although a number of Baeyer-Villiger monooxygenases (EC 1.14.13.22) have been isolated from a variety of organisms, the NADPH-dependent cyclohexanone monooxygenase from the bacterium Acinetobacter sp. NCIB 9871 has been studied in the most detail. This enzyme catalyzes the second step in a catabolic pathway that allows the cells to utilize cyclohexanol as their sole source of carbon and energy. The ability of the purified enzyme or whole Acinetobacter cells to oxidize a diverse array of cyclic ketones to the corresponding lactones with high stereoselectivity is well established [Stewart et al., 1998].

NADPH-dependent cyclohexanone monooxygenase from Acinetobacter sp. has been expressed in baker's yeast. These genetically modified yeast cells can be used as biocatalysts in 4-alkilcyclohexanone oxidation to produce caprolactones (Fig. 15) with high enantiomeric excess [Stewart et al., 1998].<smiles>[R]C1CCC(=O)CC1</smiles>

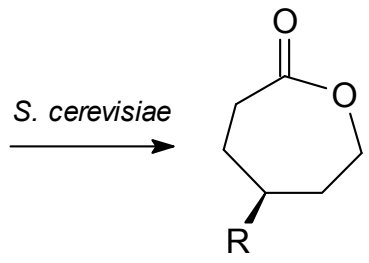

Fig. 15. 4-alkilcyclohexanone oxidation with baker's yeast [Stewart et al., 1998]

The same recombinant yeast can completely convert 2- and 3-substituted cyclopentanones and 2 and 3- substitued cyclohexanones. These reactions are found to be highly enantioselective, allowing the possibility to synthesize different stereoisomers depending upon the size of the ring and the sort of alkyl group. As a result of these modifications, reduction of the carbonyl group is minimized [Kayser et al., 1999; Stewart et al., 1998]. Chiral lactones are useful building blocks in the pharmaceutical industry since bicyclic and polycyclic lactones have received considerable attention as antitumor compounds, cardiac sarcoplasmic reticulum $\mathrm{Ca}^{2+}$ pumping ATPase activators and as useful intermediates in the synthesis of potent drugs for the treatment of glaucoma and hypertension [Alphand et al., 2003].

\subsection{Hydrolysis and esterification}

About two thirds of reported practical biotransformations may be categorized as hydrolytic reactions involving ester and amide bonds using proteases, esterases or lipases [Loughlin, 2000]. Lipases, in addition to their biological significance, hold tremendous potential for exploitation in biotechnology. They display exquisite chemo-, regio-, and stereoselectivity, do not usually require cofactors and are readily available from microbial organisms [Jaeger \& 
Eggert, 2002]. The crystal structure of many lipases has been solved, facilitating considerably the design of rational engineering strategy. For these reasons lipases are commonly used in ester synthesis, acylglycerols modifications and in biodiesel production. Consequently, lipase genes are often integrated with host cell genomes of other microorganisms.

"True" lipases are defined as carboxylesterases, catalyzing the bioconversion of long-chain acylglycerols. The essential difference between lipases and esterases is the former act at the water-lipid interface, requiring a micelle formation by a water-insoluble substrate [Gill \& Parish, 1997]. Although S. cerevisiae produces several hydrolytic enzymes such as esterases and lipases [Białecka-Florjańczyk et al., 2010] (some of which have been isolated), it is generally used as a host organism to express other microbial lipases of special catalytic activity.

\subsubsection{Cell surface engineered baker's yeast in esterification reactions}

The whole-cell catalysed reactions are often limited by barrier functions of the cell wall or membrane and thus the localization of enzyme, (extracellular, intracellular and membrane bound) plays an important role in lipase activity [Deive et al., 2009]. By the means of molecular engineering, the cell surface properties can be designed by displaying various functional proteins, especially enzymes. This technique provides to avoid mass transport problems of substrate and/or product across the cell membrane as the enzyme, necessary for catalysis, is displayed on the cells surface. Besides the anchoring to the cell surface usually results in increased biocatalyst stability. A cell surface engineering system of yeast Saccharomyces cerevisiae has been established and novel yeasts displaying lipases in their active form on the cell surface were constructed [Ueda \& Tanaka, 2000]. Lipase-displaying whole-cell yeast biocatalysts have recently attracted attention for their use in biodiesel synthesis.

Biodiesel, a fuel for diesel engines, represents an alternative environmentally-friendly source of energy obtained from renewable materials. It is produced via tranesterification of vegetable oils with alcohols (methanol or ethanol) and comprises fatty acid methyl (FAME, Fig. 16) or ethyl esters (FAEE). For ecological reasons, the enzymatic transesterification is becoming of increasing interest, yet the high cost of enzymes (lipases) obstructs its full industrial application [Akoh et al., 2007, Ribeiro et al., 2011]. Much research has focused on methods which allow increased whole-cell biocatalytic activity and stability through changes in microorganism culture conditions, their immobilization and application of genetic engineering techniques [Kucharski et al., 2009].<smiles>[R]C(=O)OCC(COC([R])=O)OC([R])=O</smiles>

triacylglycerol

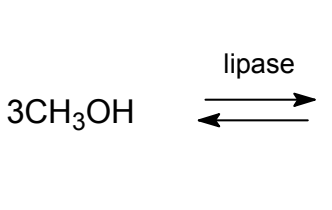

methanol

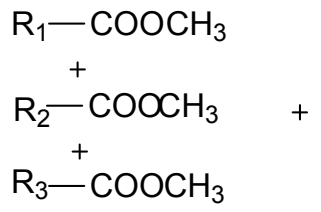

Fatty acids methyl esters (FAME)<smiles>OCC(O)CO</smiles>

glycerol

Fig. 16. Biodiesel production scheme

It has been shown that the application of recombinant baker's yeast reduces the number of operations required in biodiesel production and simplifies the removal of glycerol [Fukuda 
et al., 2008; Takahashi et al., 1998, 1999]. The possibilities of heterologous expression of nonspecific lipases such as Candida rugosa, Pseudomonas cepacia and Pseudomonas fluorescens has been reported, all of which exhibit relatively high conversion rates and methanol tolerance [Fukuda et al., 2008]. Whole-cell yeast biocatalysts, which intracellularly overproduce a recombinant lipase with a pro-sequence from Rhizopus oryzae (rProROL) were constructed and the content of active lipase in S. cerevisiae cells was maximized by optimizing the cultivation procedure. Lipase from Rhizopus oryzae (ROL) was chosen because its secretory production has been accomplished in S. cerevisiae. Overproducing ROL lipase baker's yeast strain MT8-1 was permeabilized and used for the synthesis of FAME with $71 \%$ efficiency [Takahashi et al., 1999].

The cell surface engineering of yeasts by which functional proteins are displayed on the cell surface has enabled the development of a novel strategy for whole-cell biocatalysts. To enhance lipase activity and preserving the conformation of the active site near the Cterminal portion a linker peptide (spacer) consisting of the Gly/Ser repeated sequence was inserted at the C-terminal position. The display of active lipase from Rhizopus oryzae on the S. cerevisiae cell surface resulted in production of 2,3-dimercaptopropan-1-ol tributyl ester and insoluble triolein [Washida et al., 2001]. This eliminates the cell disintegration step, allowing the production of intracellular enzyme and subsequent ease of separation of the products from the catalysts. Both these factors influences the costs of the process, making it more cost effective [Takahashi et al., 1998]. There are other examples of enzymes displayed on baker's yeast surface such as the lipase CaLIP4 from Candida albicans [Breinig et al., 2002], lipase A from Bacillus subtilis [Mormeneo et al., 2008; Roustan et al., 2005] and lipase L1 from Bacillus stearothermophilus [Breinig et al., 2002].

The other tendency in S. cerevisiae modifications reflects the broadening of kinds of carbon sources that can be utilized by yeast cells for biodiesel production purposes

Though biodiesel synthesis is the main area of cell wall engineered yeast application nevertheless it was employed in some other esterifications. To improve cost-efficiency a whole-cell biocatalysts CALB-displaying was constructed using the Flo1p short (FS) anchor system. Lyophilized yeast cells were applied to an ester synthesis reaction at $60^{\circ} \mathrm{C}$ using adipic acid and butanol as substrates [Tanino et al., 2007]. Similar whole cell catalyst have been applied in the esterification of hexanoic acid with ethanol, yielding $98.2 \%$ of the ester under optimum conditions [Han et al., 2009].

Recombinant $R$. oryzae lipase (ROL) displayed on the $S$. cerevisiae cell surface was used in the resolution of enantiomers of $(R, S)$-1-phenylethanol, which serves as one of the important chiral building blocks. During enantioselective transesterification of this alcohol with vinyl acetate (Fig. 17) the yield of (R)-1-phenylethyl acetate reached $97 \%$ with $93 \%$ enantiomeric excess [Matsumoto et al., 2004].

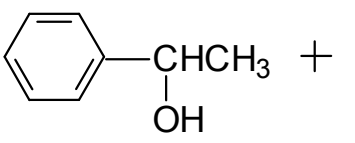

$(R S)$-1-phenylethanol

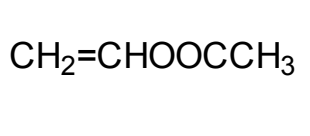

vinyl acetate

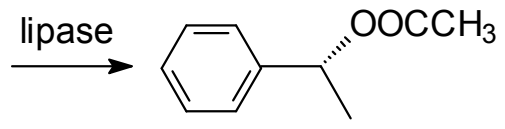

(R)-1-phenylethylacetate

Fig. 17. Synthesis of $(R)-1$-phenylethylacetate 
The ROL-displaying yeast whole-cell biocatalyst catalyzed the stereospecific hydrolysis of the pharmaceutical precursor $(R, S)$-1-benzyloxy-3-chloro-2-propyl monosuccinate. The isomer $(R)$ was isolated with the ee up to $95,5 \%$ (Fig. 18). Rhizopus oryzae lipase was displayed on the cell surface of Saccharomyces cerevisiae via the Flo1 N-terminal region (1100 amino acids), which corresponds to a flocculation functional domain [Nakamura Y., 2006].<smiles>O=C(O)CCC(=O)OC[C@@H](CCl)Oc1ccccc1</smiles><smiles>O=C(O)CCC(=O)OC(CCl)COc1ccccc1</smiles>

Fig. 18. Stereospecific hydrolysis of of $(R, S)$-1-benzyloxy-3-chloro-2-propyl monosuccinate

\subsection{L-malic acid production}

Biotransformation, using whole cells of modified S. cervisiae can be applied in the synthesis of L-malic acid (Fig. 19). Besides the food industry (acidulant E 296), malic acid has extensive application in the pharmaceutical and cosmetic industries. L-malic acid is enzymatically produced via the hydration of maleic or fumaric acid (FA) catalysed by fumarase (EC 4.2.1.2) from bacteria such as Brevibacterium ammoniagenses and B. flavum [Yazawa et al., 2010].

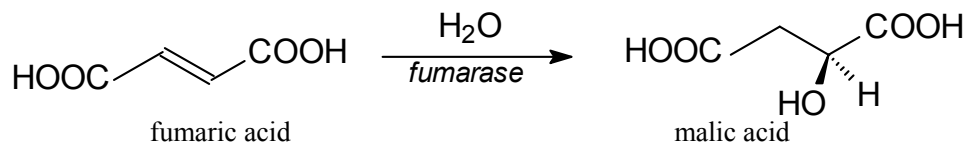

Fig. 19. Biotransformation of fumaric acid to L-malic acid

In the 1990s, production of L-malic acid from fumaric acid using S. cerevisiae cells was studied extensively with the amount of by-products minimized using modified $S$. cerevisiae cells with many copies of the fumarase gene as a biocatalysts [Presečki et al., 2007]. Conversion of fumaric acid to L-malic acid was carried out also in a bioreactor divided into three compartments by two supported liquid membranes. The yeast was immobilized in small glasslike beads of an alginate-silicate solgel matrix, allowing the reaction to reach almost $100 \%$ the conversion with only small amount of succinic acid produced. This was much higher than the $70 \%$ conversion rate found in industrial processes [Peleg et al., 1990].

\section{Conclusions}

S. cerevisiae has an enormous potential for the production of low and high molecular weight compounds by acting as an heterologous host and expressing biosynthetic enzymes or pathways. By coupling multiple enzymes, metabolic pathways in a single cell are created. This eliminates the need for purification of the chemical intermediates and the desired products can be prepared from simple, inexpensive and renewable materials. In the future the metabolic engineering of yeast may lead to an alternative production systems, helping overcome the limited availability of biologically active, commercially valuable and nutritionally important 
plant secondary metabolites compounds. It should be possible to significantly reduce development and costs of these microbial cell factories.

S. cerevisiae may be used as a whole-cell biocatalysts in the biotransformations, mostly in reduction or hydrolysis reactions. Modern research has lead to improvements in the catalytic ability of baker's yeast, including the surface display of enzymes, optimization or increase of the cofactor availability in bioreduction reactions and gene knock-out, which eliminates the activity of enzymes with conflicting, unwanted stereoselectivity.

It was shown that genetically engineered baker's yeast has a great potential as a biocatalysts in many branches of chemistry. The fact is that it is impossible to enumerate all of the published application of modified $S$. cerevisiae cells as to improve valuable chemicals production. It is worth mentioning that there are still problems not solved. Many studies regarding S. cerevisiae metabolic engineering for lignocellulosic biomass utilization have been provided, but this process involving baker's yeast is still insufficient for industrial bioprocesses mainly due to low rate of reaction. Nevertheless it can be predicted that engineered baker's yeast would be an efficient tool in chemical processes as to improve people lives.

\section{Acknowledgements}

This work was supported by Grant No N N209 107639 from the State Committee for Scientific Research, Ministry of Scientific Research and Information Technology, Poland.

\section{References}

Abbott, D.A.; ZellC, R.M.; Pronk, J.T. \& Maris A.J. (2009), Metabolic engineering of Saccharomyces cerevisiae for production of carboxylic acids: current status and challenges, FEMS Yeast Research, Vol.9, No.8, (December 2009), pp. 1123-1136, ISSN 1567-1356

Almqvist, F.; Eklund, L. \& Frejd, T. (1993), An improved procedure for the synthesis of bicyclo[2.2.2]octane-2,6-dione, Synthetic Communications, Vol.6, (1993), pp. 957-960, ISSN 0039-7911

Alphand, V.; Carrea, G.; Wohlgemuth, R.; Furstoss, R. \& Woodley, J.M. (2003), Towards large-scale synthetic applications of Baeyer-Villiger monooxygenases, Trends in Biotechnology, Vol. 21, No. 7, (July 2003), pp. 318-323, ISSN 0167-7799

Akoh, C.C.; Chang, S.W.; Lee, G.C. \& Shaw J.F. (2007). Enzymatic approach to biodiesel production, J Agric Food Chem. Vol. 55, No.22, pp 8995-9005, ISSN 1520-5118

Arsenault, P.R.; Wobbe, K.K. \& Weathers P.J. (2008), Recent advances in artemisinin production through heterologous expression, Current Medicinal Chemistry, Vol.15, No.27, (February 2008), pp. 2886-2896, ISSN 0929-8673

Białecka-Florjańczyk, E. \& Majewska, E. (2006), Biotransformacje z udziałem drożdży Saccharomyces cerevisiae, Biotechnologia, Vol.3, (2006), pp. 113-133, ISSN 0860-7796

Białecka-Florjańczyk, E.; Krzyczkowska, J. \& Stolarzewicz I. (2010), Catalytic activity of baker's yeast in ester hydrolysis, Biocatalysis and Biotransformation, Vol.28, No.4, (July 2010), pp. 288-291, ISSN 1024-2422 
Breinig, F. \& Schmitt, M.J. (2002), Spacer-elongated cell wall fusion proteins improve cell surface expression in the yeast Saccharomyces cerevisiae, Applied Microbiology and Biotechnology, Vol.58, No.5, (April 2002), pp. 637-640, ISSN 0175-7598

Carlquist, M.; Wallentin, C.; Warnmark, K. \& Gorwa-Grauslund, M.F. (2008), Genetically engineered Saccharomyces cerevisiae for kinetic resolution of racemic bicyclo[3.3.1]nonane-2,6-dione, Tetrahedron: Asymmetry, Vol.19, No.19, (October 2008), pp. 2293-2295, ISSN 0957-4166

Carlquist, M.; Olsson, C.; Bergdahl, B.; Niel, E.W.J.; Gorwa-Grauslund, M.F. \& Frejd, T. (2009), Kinetic resolution of racemic 5,6-epoxy-bicyclo[2.2.1]heptane-2-one using genetically engineered Saccharomyces cerevisiae, Journal of Molecular Catalysis B, Vol.58, No.1-4, (June 2009), pp. 98-102, ISSN 1381-1177

Celińska E. (2010), Debottlenecking the 1,3-propanediol pathway by metabolic engineering, Biotechnology Advances, Vol.28, No.4, (July-August 2010), pp. 519-530, ISSN 07349750

Chang, M.C. \& Keasling, J.D. (2006), Production of isoprenoid pharmaceuticals by engineered microbes. Nature Chemical Biology, Vol.2, No.12, (December 2006), pp. 674-681, ISSN 1552-4450

Chemler, J.A.; Yan, Y. \& Koffas, M.A.G. (2006), Biosynthesis of isoprenoids, polyunsaturated fatty acids and flavonoids in Saccharomyces cerevisiae, In: Microbial Cell Factories, Vol.5, 23.05.2006, Available from:

http://www.ncbi. nlm. nih.gov/ pmc/articles/PMC1533850/

Chu, B.C. \& Lee, H. (2007), Genetic improvement of Saccharomyces cerevisiae for xylose fermentation, Biotechnology Advances, Vol. 25, No. 5, (September-October 2007), pp. 425-441, ISSN 0734-9750

Csuk, R. \& Glanzer, B. (1991), Baker`s yeast mediated transformations in organic chemistry, Chemical Reviews, Vol. 91, No.1, (January 1991) pp. 49-97, ISSN 0009-2665

Daum, G.; Lees, N.D., Bard, M. \& Dickson R. (1998), Biochemistry, cell biology and molecular biology of lipids of Saccharomyces cerevisiae, Yeast, Vol.14, No.16, (December 1998), pp. 1471-1510, ISSN 0749-503X

Deive, F.J.; Carvalho, E.; Pastrana, L.; Rua, M.L.; Longo, M.A. \& Sanroman, M.A. (2009), Strategies for improving extracellular lipolytic enzyme production by Thermus thermophilus HB27, Bioresource Technology, Vol.100, No.14, (July 2009), pp. 36303637, ISSN 0960-8524

Dejong, J.M.; Liu, Y.; Bollon, A.P.; Long, R.M.; Jennewein, S.; Williams, D. \& Croteau, R.B. (2006), Genetic engineering of taxol biosynthetic genes in Saccharomyces cerevisiae, Biotechnology and Bioengineering, Vol.93, No.2, (February 2006), pp. 212-224, ISSN 0006-3592

Dumas, B.; Brocard-Masson, C.; Assemat-Lebrun, K. \& Achstetter, T. (2006), Hydrocortisone made in yeast: Metabolic engineering turns a unicellular microorganism into a drug-synthesizing factory, Biotechnology Journal, Vol.1, No.3, (March 2006), pp. 299307, ISSN 1860-6768

Engelking, H.; Pfaller, R.; Wich, G. \& Weuster-Botz, D. (2006), Reaction engineering studies on $\beta$-ketoester reductions with whole cell recombinants Saccharomyces cerevisiae, 
Enzyme and Microbial Technology, Vol.38, No.3-4, (February 2006), pp.536-544, ISSN 0141-0229

Faber, K. (2004), Biotransformations in organic chemistry, Springer-Verlag, New York, ISBN 3540-6334-7

Fukuda H., Hama S., Tamalampudi S. \& Noda H. (2008). Whole-cell biocatalysts for biodiesel fuel production, Trends in Biotechnology, Vol.26, No.12, (December 2008), pp. 668-672, ISSN 0167-7799

Gill, J. \& Parish, J. (1997), Lipases - Enzymes at an interface, Biochemical Education, Vol.25, No.1, (January 1997), pp. 2-5, ISSN 0307-4412

Goffeau, A.; Barrell, B.G.; Bussey, H.; Davis, R.W.; Dujon, B.; Feldmann, H.; Galibert, F.; Hoheisel, J.D.; Jacq, C.; Johnston, M.; Louis, E.J.; Mewes, H.W.; Murakami, Y.; Philippsen, P.; Tettelin, H. \& Oliver, S.G.,(1996) Life with 6000 genes, Science, Vol. 74, No.546, (October 1996), pp. 546, 563-567, ISSN 0036-8075

Hahn-Hägerdal, B.; Karhumaa, K.; Jeppsson, M. \& Gorwa-Grauslund, M.F. (2007), Metabolic engineering for pentose utilization in Saccharomyces cerevisiae, Advances in Biochemical Engineering/ Biotechnology, Vol.108, pp. 147-177, ISSN 0724-6145

Han, S.; Pan, Z.; Huang D.; Ueda, M.; Wang, X \& Lin, Y. (2009), Highly efficient synthesis of ethyl hexanoate catalyzed by CALB-displaying Saccharomyces cerevisiae whole-cells in non-aqueous phase, Journal of Molecular Catalysis: B, Vol.59, No.1-3, (July 2009), pp. 168-172, ISSN 1381-1177

Huang, B.; Guo, J.; Yi, B.; Yu, X.; Sun L. \& Chen, W. (2008), Heterologous production of secondary metabolites as pharmaceuticals in Saccharomyces cerevisiae, Biotechnology Letters, Vol.30, No.7, (July 2008), pp.1121-1137, ISSN 0141-5492

Inui, M.; Suda, M.; Kimura, S.; Yasuda, K.; Suzuki, H.; Toda, H.; Yamamoto, S.; Okino, S.; Suzuki, N. \& Yukawa, H. (2008), Expression of Clostridium acetobutylicum butanol synthetic genes in Escherichia coli, Applied Microbiology and Biotechnology, Vol.77, No. 6 (January 2008), pp. 1305-1316, ISSN 0175-7598

Ishida, N.; Saitoh, S.; Ohnishi, T.; Tokuhiro, K.; Nagamori, E.; Kitamoto, K. \& Takahashi, H. (2006), Metabolic engineering of Saccharomyces cerevisiae for efficient production of pure L-(+)-lactic acid, Applied Biochemistry and Biotechnology, Vol.131, No.1-3, (March 2006), pp. 795-807, ISSN 0273-2289

Jaeger, K.E. \& Eggert, T. (2002), Lipases for biotechnology, Current opinions in biotechnology, Vol.13, No. 4, (August 2002) ,pp. 390-397, ISSN 0958-1669

Jiang, H.X.; Wood, K.V. \& Morgan, J.A. (2005), Metabolic engineering of the phenylpropanoid pathway in Saccharomyces cerevisiae, Applied and Environmental Microbiology, Vol.71, No.6, (June 2005), pp. 2962-2969, ISSN 0099-2240

Johanson, T.; Katz, M. \& Gorwa-Grauslund, M.F. (2005), Strain engineering for stereoselective bioreduction of dicarbonyl compounds by yeast reductases, FEMS Yeast Research, Vol.5, No.6-7, (January 2005), pp. 513-525, ISSN 1567-1356

Johanson, Y.; Carlquist, M.; Olsson, C.; Rudolf, A.; Frejd, T. \& Gorwa-Grauslund, M.F. (2008), Reaction and strain engineering for improved stereoselective whole-cell reduction of a bicyclic diketone, Applied Microbiology and Biotechnology, Vol.77, No.5, (January 2008), pp. 1111-1118, ISSN 0175-7598 
Katz, M.; Sarvary, I.; Frejd, T.; Hahn-Hagerdal, B. \& Gorwa-Grauslund, B. (2002), An improved stereoselective reduction of a bicyclic diketone by Saccharomyces cerevisiae combining process optimization and strain engineering, Applied Microbiology and Biotechnology, Vol.59, No.6, (September 2002), pp. 641-648, ISSN 0175-7598

Katz M., Hahn-Hagerdal B. \& Gorwa-Grauslund M. F., (2003), Screening of two complementary collections of Saccharomyces cerevisiae to identify enzymes involved in stereo-selective reductions of specific carbonyl compounds: an alternative to protein purification, Enzyme and Microbial Technology, Vol.33, No.3 (August 2003), pp. 163-172, ISSN 0141-0229

Kayser, M. M.; Chen, G. \& Stewart, J. D. (1999), "Designer Yeast": an Enantioselective Oxidizing Reagent for Organic Synthesis Synlett., No. 1, pp. 153-158. ISSN: 09365214

Kayser, M.M.; Mihovilovich, M.D.; Kearns, J.; Feicht, A. \& Stewart, J.D. (1999), Baker's YeastMediated Reductions of a-Keto Esters and an a-Keto- $\beta$-Lactam. Two Routes to the Paclitaxel Side Chain, Journal of Organic Chemistry, Vol.64, No.18, (3 September 1999), pp. 6603-6608, ISSN 0022-3263

Kondo, A.; Tanaka, T.; Hasunuma, T. \& Ogino, C. (2010), Applications of yeast cell-surface display in bio-refinery, Recent Patents on Biotechnology, Vol.4, No.3, (November 2010), pp. 226-234, ISSN 1872-2083

Kucharski D.; Białecka-Florjańczyk E. \& Stolarzewicz I. (2009) Mikrobiologiczne metody otrzymywania biodiesla, Biotechnologia, Vol.4 No.87, pp. 74-87, ISSN 0860-7796

Loughlin, W.A. (2000), Biotransformations in organic synthesis, Biosource Technology, Vol.74, No.1, (August 2000), pp. 49-62, ISSN 0960-8524

Matsumoto, T.; Ito, M.; Fukuda, H. \& Kondo, A. (2004), Enantioselective transesterification using lipase-displaying yeast whole-cell biocatalyst, Applied Microbiology and Biotechnology, Vol.64, No.4, (May 2004), pp. 481-485, ISSN 0175-7598

Matsushika, A.; Inoue, H.; Kodaki, T. \& Sawayama, S.; Ethanol production from xylose in engineered Saccharomyces cerevisiae strains: current state and perspectives. Applied Microbiology and Biotechnology, Vol.84, No.1, (August 2009), pp. 37-53, ISSN 01757598

Mendes, F.S.; González-Pajuelo, M.; Cordier, H.; François, J.M. \& Vasconcelos I. (June 2011), 1,3-Propanediol production in a two-step process fermentation from renewable feedstock, In: Applied Microbiology and Biotechnology, 9.06.2011, Available from: http://www.springerlink.com/content/27r256n7r1638r51

Mormeneo, M.; Andres, I.; Bofill, C.; Diaz, P. \& Zuezo, J. (2008), Efficient secretion of Bacillus subtilis lipase A in Saccharomyces cerevisiae by translational fusion to the Pir4 cell wall protein, Applied Microbiology and Biotechnology, Vol. 80, No.3,(September 2008), pp. 437-445, ISSN 0175-7598

Nakamura, K.; Inoue, Y.; Shibahara, J.; Oka, S. \& Ohno, A. (1988), Asymmetric reduction of $\beta$ - and $\gamma$-nitro ketones by bakers' yeast. Tetrahedron Letters, Vol.29, No.7, (1988), pp. 4769-4770, ISSN 0040-4039

Nakamura,Y.; Matsumoto, T.; Nomoto, F.; Ueda, M.; Fukuda, H.\& Kondo, A. (2006) Enhancement of activity of lipase-displaying yeast cells and their application to 
optical resolution of (R,S)-1-benzyloxy-3-chloro-2-propyl monosuccinate, Biotechnology Progress, 22, 998-1002. ISSN 1520-6033

Nevoigt, E. (2008). Progress in metabolic engineering of Saccharomyces cerevisiae, Microbiology and Molecular Biology Reviews, Vol. 72, No. 3, (September 2008), pp. 379-412, ISSN 1092-2172

Parachin, N.S.; Carlquist, M. \& Gorwa-Grauslund, M. F. (2009), Comparison of engineered Saccharomyces cerevisiae and engineered Escherichia coli for the production of an optically pure ketoalkohol, Applied Microbiology and Biotechnology, Vol.84, No.3, (September 2009), pp. 487-497, ISSN 0175-7598

Peleg, Y.; Rokem, J.S.; Goldberg, I. \& Pines, O. (1990), Inducible overexpression of the FUM1 gene in Saccharomyces cerevisiae: localization of fumarase and efficient fumaric acid bioconversion to L-malic acid., Applied and Environmental Microbiology, Vol.56, No.9, (September 1990), pp. 2777-2783, ISSN 0099-2240

Pines, O.; Shemesh, S.; Battat, E. \& Goldberg, I. (1997), Overexpression of cytosolic malate dehydrogenase (MDH2) causes overproduction of specific organic acids in Saccharomyces cerevisiae, Applied Microbiology and Biotechnology, Vol.48, No.2, (August 1997), pp. 248-255, ISSN 0175-7598

Presečki, A.V.; Zelić, B. \& Vasić-Rački, D. (2007), Comparison of the l-malic acid production by isolated fumarase and fumarase in permeabilized baker's yeast cells, Enzyme and Microbial Technology, Vol.41, No.5, ( October 2007), pp. 605-612, ISSN 0141-0229

Pscheidt, B. \& Glieder, A.(2008) Yeast cell factories for fine chemical and API production, Microbial Cell Factories 7:25, ISSN: 1475-2859

Ralston, L.; Subramanian, S.; Matsuno, M. \& Yu, O. (2005), Partial reconstruction of flavonoid and isoflavonoid biosynthesis in yeast using soybean type I and type II chalcone isomerases, Plant Physiology, Vol.137, No.4, (April 2005), pp. 1375-1388, ISSN 0032-0889

Rao, Z.; Ma, Z.; Shen, W.; Fang, H.; Zhuge, J. \& Wang, X. Engineered Saccharomyces cerevisiae that produces 1,3-propanediol from D-glucose, Journal of Applied Microbiology, Vol.105. No.6 (December 2008), pp. 768-776, ISSN 1364-5072

Remize, F.; Roustan, J.L.; Sablayrolles, J.M.; Barre, P. \& Dequin, S. (1999), Glycerol overproduction by engineered Saccharomyces cerevisiae wine yeast strains leads to substantial changes in by-product formation and to a stimulation of fermentation rate in stationary phase, Applied and Environmental Microbiology, Vol.65, No.1, (January 1999), pp. 143-149, ISSN 0099-2240

Ribeiro B.D.; de Castro A.M.; Coelho M.A. \& Freire D.M., (2011), Production and use of lipases in bioenergy: a review from the feedstocks to biodiesel production. Enzyme Res., Epub 2011 Jul 7. ISSN: 2090-0406

Ro, D.; Paradise, E.M.; Ouellet, M.; Fisher, K.J.; Newman, K.L.; Ndungu, J.M.; Ho, K.A.; Eachus, R.A.; Ham, T.S.; Kirby, J.; Chang, M.C.Y.; Withers, S.T.; Shiba, Y.; Sarpong, R. \& Keasling, J.D. (2006), Production of the antimalarial drug precursor artemisinic acid in engineered yeast, Nature, Vol.440, (13 April 2006), pp.940-943, ISSN 0028-0836 
Rodriguez, S.; Kayser, M.M. \& Stewart, J.D, (1999), Improving the stereoselectivity of bakers' yeast reductions by genetic engineering, Organic Letters, Vol.1, No.8, (October 1999), pp. 1153-1155, ISSN 1523-7060

Rodriguez S., Schroeder K.T., Kayser M.M. \& Stewart J.D. (2000), Asymmetric synthesis of $\beta$-hydroxy esters and $\alpha$-alkyl- $\beta$-hydroxy esters by recombinant Escherichia coli expressing enzymes from baker's yeast, Journal of Organic Chemistry, Vol.65, No.8, (April 2000), pp. 2586-2587, ISSN 0022-3263

Rodriguez, S.; Kayser, M.M. \& Stewart, J.D. (2001), Highly Stereoselective Reagent for $\beta$ Keto Ester Reductions by Genetic Engineering of Baker's Yeast, Journal of the American Chemical Society, Vol.123, No.8, (February 2001), pp. 1547-1555, ISSN 0002-7863

Roustan, J.L.; Chu, A.R.; Moulin, G. \& Bigey, F. (2005), A novel lipase/acyltransferase from the yeast Candida albicans: expression and characterisation of the recombinant enzyme, Applied Microbiology and Biotechnology, Vol.68, No.2, (August 2005), pp. 203-212, ISSN 0175-7598

Sarvary, I.; Almqvist, F. \& Frejd, T. (2001), Asymmetric reduction of ketones with catecholborane using 2,6-BODOL complexes of titanium(IV) as catalysts, Chemistry - An European Journal, Vol.7, No.10, (May 2001), pp. 2158-2166, ISSN 0947-6539

Servi, S.; (1990), Baker's Yeast in Organic Synthesis, Synthesis, (1990), pp. 1-25, ISSN 15702693

Shiba, Y.; Paradise, E.M.; Kirby, J.; Ro, D.K. \& Keasling, J.D. Engineering of the pyruvate dehydrogenase bypass in Saccharomyces cerevisiae for high-level production of isoprenoids, Metabolic Engineering, Vol.9, No.2, (March 2007), pp. 160-168, ISSN 1096-7176

Steen, E.J.; Chan, R.; Prasad, N.; Myers, S.; Petzold, C.J.; Redding, A.; Ouellet, M. \& Keasling, J.D. (December 2008), Metabolic engineering of Saccharomyces cerevisiae for the production of butanol, In: Microbial Cell Factories, 3.12.2008, Available from: http://www.ncbi.nlm.nih.gov/pmc/articles/PMC2621116

Stewart, J.D.; Reed, K.W.; Martiez, C.A.; Zhu, J.; Chen, G. \& Kayser, M.M. (1998), Recombinant baker's yeast as a whole-cell catalyst for asymmetric Baeyer-Villiger oxidations, Journal of American Chemical Society, Vol.120, No.15, (1998), pp.35413548, ISSN 0002-7863

Stewart, J.D. (2000), Organic transformations catalyzed by engineered yeast cells and related systems, Current Opinion in Biotechnology, Vol.11, No.4 (August 2000), pp. 363-368, ISSN 0958-1669

Szczebara, F.M.; Chandelier, C.; Villeret, C.; Masurel, A.; Bourot, S.; Duport, C.; Blanchard, S.; Groisillier, A.; Testet, E.; Costaglioli, P.; Cauet, G.; Degryse, E.; Balbuena, D.; Winter, J.; Achstetter, T.; Spagnoli, R.; Pompon, D. \& Dumas, B. (2003), Total biosynthesis of hydrocortisone from a simple carbon source in yeast, Nature Biotechnology, Vol.21, (6 January 2003), pp. 143 - 149, ISSN 1087-0156

Takahashi, S.; Ueda, M.; Atomi, H.; Beer, H.D.; Bornscheuer, U.T.; Schmid, R.D. \& Tanaka, A. (1998), Extracellular production of active Rhizopus oryzae lipase by Saccharomyces 
cerevisiae, Journal of Fermentation and Bioengineering, 1998, Vol.86, No.2, (1998), pp. 164-168, ISSN 0922-338X

Takahashi, S.; Ueda, M. \& Tanaka, A.; (1999), Independent production of two molecular forms of a recombinant Rhizopus oryzae lipase by KEX2-engineered strains of Saccharomyces cerevisiae, Applied Microbiology and Biotechnology, Vol.52, No.4, (October 1999), pp. 534-540, ISSN 0175-7598

Tanino, T.; Ohno, T.; Aoki, T.; Fukuda, H. \& Kondo, A. (2007), Development of yeast cells displaying Candida antarctica lipase B and their application to ester synthesis reaction, Applied Microbiology and Biotechnology, Vol.75, No.6, (July 2007), pp. 13191325, ISSN 0175-7598

Toivari, M.H.; Ruohonen, L.; Miasnikov, A.N.; Richard, P. \& Penttilä, M. (2007) Metabolic engineering of Saccharomyces cerevisiae for conversion of D-glucose to xylitol and other five-carbon sugars and sugar alcohols, Applied Environmental Microbiology. Vol. 73, No. 17, pp. 5471-5476, ISSN 0099-2240

Tokuhiro, K.; Muramatsu, M.; Ohto, C.; Kawaguchi, T.; Obata, S.; Muramoto, N.; Hirai, M.; Takahashi, H.; Kondo, A.; Sakuradani, E. \& Shimizu, S. (2009), Overproduction of geranylgeraniol by metabolically engineered Saccharomyces cerevisiae, Applied and Environmental Microbiology, Vol.75, No.17 (September 2009), pp. 5536-5543. ISSN 0099-2240

Ueda, M. \& Tanaka, A. (2000), Cell surface bioengineering of yeast: construction of arming yeast with biocatalyst, Journal of Bioscience and Bioengineering, Vol.90, No.2 (2000), pp. 125-136, ISSN 1389-1723

Wang, Z.X.; Zhuge, J.; Fang, H. \& Prior, B.A. (2001), Glycerol production by microbial fermentation: a review, Biotechnology Advances, Vol.19, No.3, (June 2001), pp. 201223, ISSN 0734-9750

Washida, M.; Takahashi, S.; Ueda, M. \& Tanaka, A. (2001), Spacer-mediated display of active lipase on the yeast cell surface, Applied Microbiology and Biotechnology, Vol.56, No.56, (September 2001), pp. 681-686, ISSN 0175-7598

Veen, M. \& Lang, C. (2004), Production of lipid compounds in the yeast Saccharomyces cerevisiae, Applied Microbiology and Biotechnology, Vol.63, No. 6, (February 2008), pp. 635-646, ISSN 0175-7598

Verwaal, R.; Wang, J.; Meijnen, J.; Visser, H.; Sandmann, G.; Berg, J.A. \& Ooyen A.J.J. (2007), High-Level production of beta-carotene in Saccharomyces cerevisiae by successive transformation with carotenogenic genes from Xanthophyllomyces dendrorhous, Applied and Environmental Microbiology, Vol.73, No.13, (July 2007), pp. 4342-4350, ISSN 0099-2240

Yan, Y.; Kohli, A. \& Koffas, M.A. (2005), Biosynthesis of natural flavanones in Saccharomyces cerevisiae, Applied and Environmental Microbiology, Vol.71, No.9, (September 2005), pp. 5610-5613, ISSN 0099-2240

Yazawa, H.; Iwahashi, H.; Kamisaka, Y.; Kimura, K. \& Uemura, H. (2010), Improvement of polyunsaturated fatty acids synthesis by the coexpression of CYB5 with desaturase genes in Saccharomyces cerevisiae, Applied Microbiology and Biotechnology, Vol.87, No. 6, (August 2010), pp. 2185-2193, ISSN 0175-7598 
Young, E.; Lee, S. \& Alper H. (November 2010), Optimizing pentose utilization in yeast: the need for novel tools and approaches, In: Biotechnology for Biofuels 2010, 16.09.2010, Available from:

http://www.biotechnologyforbiofuels.com/content/3/1/24 


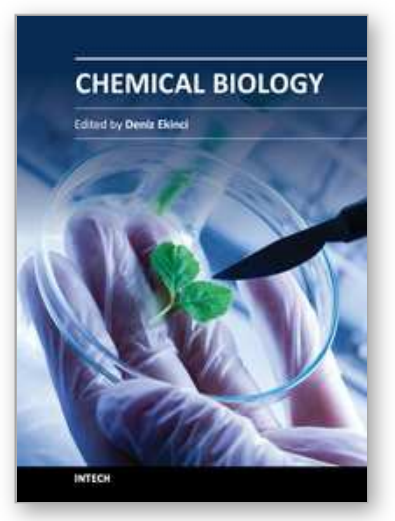

\author{
Chemical Biology \\ Edited by Prof. Deniz Ekinci
}

ISBN 978-953-51-0049-2

Hard cover, 444 pages

Publisher InTech

Published online 17, February, 2012

Published in print edition February, 2012

Chemical biology utilizes chemical principles to modulate systems to either investigate the underlying biology or create new function. Over recent years, chemical biology has received particular attention of many scientists in the life sciences from botany to medicine. This book contains an overview focusing on the research area of protein purification, enzymology, vitamins, antioxidants, biotransformation, gene delivery, signaling, regulation and organization. Particular emphasis is devoted to both theoretical and experimental aspects. The textbook is written by international scientists with expertise in synthetic chemistry, protein biochemistry, enzymology, molecular biology, drug discovery and genetics many of which are active chemical, biochemical and biomedical research. The textbook is expected to enhance the knowledge of scientists in the complexities of chemical and biological approaches and stimulate both professionals and students to dedicate part of their future research in understanding relevant mechanisms and applications of chemical biology.

\title{
How to reference
}

In order to correctly reference this scholarly work, feel free to copy and paste the following:

Ewa Białecka-Florjańczyk and Agata Urszula Kapturowska (2012). Genetically Modified Baker's Yeast Saccharomyces cerevisiae in Chemical Synthesis and Biotransformations, Chemical Biology, Prof. Deniz Ekinci (Ed.), ISBN: 978-953-51-0049-2, InTech, Available from: http://www.intechopen.com/books/chemicalbiology/genetically-modified-baker-s-yeast-saccharomyces-cerevisiae-in-chemical-synthesis-andbiotransformat

\section{INTECH}

open science | open minds

\section{InTech Europe}

University Campus STeP Ri

Slavka Krautzeka 83/A

51000 Rijeka, Croatia

Phone: +385 (51) 770447

Fax: +385 (51) 686166

www.intechopen.com

\section{InTech China}

Unit 405, Office Block, Hotel Equatorial Shanghai

No.65, Yan An Road (West), Shanghai, 200040, China

中国上海市延安西路65号上海国际贵都大饭店办公楼 405 单元

Phone: +86-21-62489820

Fax: $+86-21-62489821$ 
(C) 2012 The Author(s). Licensee IntechOpen. This is an open access article distributed under the terms of the Creative Commons Attribution 3.0 License, which permits unrestricted use, distribution, and reproduction in any medium, provided the original work is properly cited. 